\title{
Virus-Related Malignant Neoplasm
}

National Cancer Institute

\section{Source}

National Cancer Institute. Virus-Related Malignant Neoplasm. NCI Thesaurus. Code C27673.

This category currently includes only malignancies in which there is a well documented association between the neoplastic process and a specific virus as a causative agent.-2003 